\title{
Psychological Impact and Associated Factors During the Containment Stage of Covid-19 Epidemic Among College Students in China
}

\section{Mingyu Si}

Chinese Academy of Medical Sciences and Peking Union Medical College https://orcid.org/0000-0002-8372-9301

Xiao-You Su ( $\nabla$ suxiaoyou@hotmail.com )

Department of Epidemiology and Biostatistics, School of Population Medicine and Public Health, Chinese Academy of Medical Sciences and Peking Union Medical College, Beijing, China

Yu Jiang

Chinese Academy of Medical Sciences and Peking Union Medical College

Wen-Jun Wang

Jining Medical College: Jining Medical University

Xiao-Fen Gu

Xinjiang Medical University Affiliated Tumor Hospital

Li Ma

Dalian Medical University

Jing Li

Sichuan University West China School of Public Health

Shao-Kai Zhang

Affiliated Tumor Hospital of Zhengzhou University: Henan Cancer Hospital

Ze-Fang Ren

Sun Yat-Sen University School of Public Health

Yuan-Li Liu

Chinese Academy of Medical Sciences and Peking Union Medical College

You-Lin Qiao

Chinese Academy of Medical Sciences and Peking Union Medical College

\section{Research}

Keywords: COVID-19, College student, China, Psychological, Posttraumatic stress disorder, Depression

Posted Date: September 28th, 2020

DOI: https://doi.org/10.21203/rs.3.rs-80603/v1

License: () (7) This work is licensed under a Creative Commons Attribution 4.0 International License. Read Full License 


\section{Abstract}

Background College students are a uniquely vulnerable group and may experience high stress levels due to COVID-19. This study aims to identify the the psychological state and related factors on Chinese college students during the initial phases of the COVID-19 pandemic.

Methods From February 23 to March 5, 2020, a cross-sectional online survey was conducted among 3606 college students from seven provinces in China using standard questionnaires measuring adverse psychological outcomes and related factors including Impact of Event Scale-6 (IES-6), Depression, Anxiety and Stress Scale (DASS), Perceived Social Support Scale (PSSS) and Simplified Coping Style Questionnaire (SCSQ). Exploratory factor analysis (EFA) were used to determine underlying constructs of the perceived threat items. Multivariate regression was used to explore the determinants of adverse psychological impact.

Results Posttraumatic stress (PTS) were prevalent in this sample of college students, and $34.22 \%$ met the cut-off for posttraumatic stress disorder (PTSD). The proportion of having mild to extremely severe symptoms of depression, anxiety and stress were $15.70 \%, 13.31 \%$ and $7.10 \%$, respectively. The impact of closed-off management on life, perceived threat and passive coping strategies were positively correlated to PTS and DASS scores, while knowledge score, perceived social support and active coping strategies were negatively correlated to DASS scores.

Conclusions In summary, adverse psychological symptoms were prevalent among college students in China during the COVID-19 epidemic. Identifying vulnerable populations and formulating correspondingly psychological interventions would be beneficial to improve the mental health during the COVID-19 epidemic.

\section{Introduction}

An outbreak of the Coronavirus Disease 19 (COVID-19) infection began in December 2019 and as of September 13, 2020 has resulted in 28637952 cases and 917417 deaths worldwide (3.20\% of total cases) [1]. In China alone, there were 90763 reported cases and 4743 people have died due to COVID-19 [2]. Given the serious situation with COVID-19, the World Health Organization (WHO) declared it a Public Health Emergency of International Concern (PHEIC) on January 30, 2020 and due to unprecedented spread of the virus it was redefined as a global pandemic on March 11, 2020 [3]. Since the beginning of the outbreak many countries have adopted strict measures to control the outbreak, including nationwide lockdowns, home isolation, quarantine, and social distancing.

Numerous studies have examined the mental health effects associated with other infectious disease outbreaks including the 2003 Severe Acute Respiratory Syndrome (SARS) epidemic and Middle East Respiratory Syndrome (MERS) pandemic [4,5]. Populations that have experienced infectious disease outbreaks have reported psychological distress, anxiety, depression, and post-traumatic stress disorder (PTSD) [4-6]. Comparison of mortality between SARS, MERS and COVID-19 indicated that to date COVID-19 is the more deadly disease [7]. The high mortality, confusion and fear of the unknown with COVID-19 shortage of medical personnel and supplies, and the impact of the epidemic on the economy and education put people at a high risk of developing mental health problems both in China and worldwide.

College students are a uniquely vulnerable group and may experience high stress levels due to COVID-19. College students cannot resume school at the normally scheduled times and their regular routines are disrupted in a population who are still developing self-discipline and emotional control [8]. In a study among college students in Hong Kong during the outbreak of SARS, $91 \%$ of healthcare students and $84 \%$ of non-healthcare students reported positive psychological responses [9]. Most college students have not experienced the serious measures to control the COVID-19 pandemic in their lifetime and little is known about the effects of the epidemic on the mental health of college students in affected countries, including China.

The current study evaluated the psychological state, including depression, anxiety, stress, and posttraumatic stress (PTS) experienced by Chinese university students, and assessed the related factors during the initial phases of the COVID-19 pandemic. The results of this study may assist government and healthcare agencies in developing interventions by better understanding the causes of adverse psychological outcomes to alleviate stress in college students in the event of future outbreaks.

\section{Materials And Methods 2.1 Setting and participants}

We conducted a cross-sectional survey from February 23 to March 5, 2020, when the COVID-19 outbreak showed a downward trend of new cases in China and an upward trend overseas. Due to the isolation and social distancing measures recommended by the Chinese government, the questionnaire survey and corresponding data was collected electronically via the internet. Potential participants from seven geographical territories in mainland China were electronically invited by teachers from our partner universities.

The study was approved by the Ethics Committee of Jining Medical University of Shandong Province on February 12, 2020. Potential participants provided electronic informed consent by answering if they were willing to participate in the questionnaire survey voluntarily. After answering yes to the participation question, they were directed to complete the self-reported questionnaire.

\subsection{Measurements}

The structured questionnaire was designed to encompass the following areas: (1) demographic characteristics including gender, age, place of residence, and education, (2) health status including history of chronic disease(s) and health condition(s), (3) variables related to COVID-19 (e.g. whether they were 
quarantined, levels of concern to the outbreak), (4) knowledge about COVID-19, (5) daily perceived social support and coping strategies, (6) student perceptions of threat associated with COVID-19, (7) the psychological impact of the COVID-19 including perceived stress, anxiety, depression and PTSD.

\subsubsection{The perceived social support scale (PSSS)}

The 12-item perceived social support scale (PSSS) assesses a respondent's perceived support on a 7-point Likert scale (1 = strongly disagree; 7 = strongly agree) [10]. Total possible scores range from 12 to 84 , with higher scores indicating higher levels of perceived support obtained from family, friends and significant others. The Chinese version of the PSSS has adequate internal consistency (Cronbach's a $=0.89$ ) [11] and was 0.943 in the present study.

\subsubsection{The Simplified Coping Style Questionnaire}

The 20-item Simplified Coping Style Questionnaire (SCSQ) measures an individual's coping style to understand its relationship with psychosomatic health using a 4-point Likert scale ( $0=$ never; $3=$ very often) $[12,13]$. The SCSQ includes two dimensions, the first $1-12$ items focuses on reflecting the traits of active coping (AC) and the remaining 8 items to measure passive coping (PC) [14]. Previous studies have shown that this scale has good reliability and validity for both active coping styles (Cronbach's a $=0.89$ ) and passive coping styles (Cronbach's $a=0.78$ ). In the present study, the Cronbach's alpha coefficients for the two dimensions of SCSQ were 0.886 and 0.803 , respectively.

\subsubsection{Perceived threat}

Participants' perceived threat by COVID-19 was measured by 10 items developed based on earlier studies [15-17]. 'I feel anxious and scared when thinking of COVID-19', 'I feel that I can be infected anytime and anywhere', 'Worried about being infected and sick', 'Worried that the epidemic will affect my study plan', 'Worried that the epidemic will affect my test plan', 'Worried that the epidemic will affect my social plan', 'Worried that the epidemic will affect my work plan', 'Worried about the closure of tourism and/or trade, affecting international cooperation and exchanges', 'Worried about the lack of goods due to the interruption of import and export logistics', and 'Worried about rising prices and rising exchange rates'. For each individual item, the answer is on a 5-point Likert scale ('strongly disagree' to 'strongly agree'), and a higher total score indicated a greater perceived threat by the COVID-19 outbreak. The Chronbach's alpha of the 10item perceived threat was 0.810 .

\subsubsection{Impact of Event Scale-6 (IES-6)}

The Impact of Event Scale-6 (IES-6) is an abbreviated 6-item version of The Impact of Event Scale-revised (IES-R). Respondents are asked to report the psychological impact after exposure to a crisis situation within 7 days of exposure using a 5-point Likert scale $(0=$ not at all; $4=$ extremely) [18]. IES-R is validated among Chinese population [19] and the Cronbach's alpha was 0.845 in the present study.

\subsubsection{Depression, Anxiety and Stress Scale (DASS)}

Depression, anxiety, and stress symptoms were measured using the Chinese brief version of the Depression, Anxiety, and Stress Scale (DASS-21), a selfreported 21-item scale used for assessing psychological distress. Participants gave item ratings according to their experience over the past week on a 4-point scale rating from 0 (did not apply to me at all) to 3 (applied to me very much). The DASS-21 consists of three subscales (each with 7 items) measuring depression, anxiety, and stress $[20,21]$ and higher scores denote a greater severity of psychological symptoms [22, 23]. The DASS-21 has been validated in Chinese populations and the Chronbach's alpha of the three subscales of DASS were $0.823,0.811$ and 0.861 for depression, anxiety and stress respectively and 0.935 for the total DASS in the present study.

\subsection{Statistical Analysis}

The data were analyzed using SPSS 22.0. Statistical significance was defined as a two-tailed $P$-value less than 0.05 . For reliability, internal consistency was assessed by calculating Cronbach's a values. A descriptive analysis of the demographic data was conducted to describe the sample characteristics. Categorical variables were expressed as frequencies and percent distributions, while continuous variables were presented as means \pm standard deviations (SD). Age was divided into three categories $\leq 20,21-22$ and $\geq 23$ according to the frequency distribution and analyzed as a categorical variable. The prevalence of psychological outcomes were derived according to the cut-off values routinely used in previous studies. Exploratory factor analysis (EFA) based on principal component and varimax rotation methods were used to determine underlying constructs of the perceived threat items. Linear regression was performed and Pearson correlation coefficients were calculated to assess associations between psychological impact and other study variables. Multiple linear regression was used to explore psychological impact and their potential factors by adjusting the variables significant in univariate analysis at $P \leq 0.10$.

\section{Results}

\subsection{Sociodemographic characteristics}

Of 5059 college students approached, 3606 completed the questionnaire survey (response rate $=71.28 \%$ ). Sample characteristics and related association with adverse psychological outcomes of the COVID-19 outbreak are presented in Table 1 . The majority of respondents (71.88\%) were female, $40.68 \%$ were age less than 20 years, $57.38 \%$ were rural residents, $85.44 \%$ were undergraduate students, $98.03 \%$ never had a chronic disease, $93.59 \%$ reported they have good health, and $48.42 \%$ were majored in medicine in school.

Furthermore, $86.22 \%$ of the respondents were aware of the news that the WHO defined COVID-19 as a PHEIC on January $30,43.48 \%$ were highly concerned about the epidemic, and $34.50 \%$ believed that COVID-19 would cause a global outbreak. In addition, $0.50 \%$ had confirmed cases among relatives and friends, $58.60 \%$ had ever been quarantined or isolated during the outbreak. When asked to use 1-10 points to evaluate the impact of closed-off management on their daily lives, the average value obtained was 5.55 points $(S D=2.572)$, and the mean knowledge score of respondents was $10.351(S D=1.273)(T a b l e 1,2)$. 
Table 1

Association between demographic variables and the psychological impact of the COVID-19 outbreak during the epidemic ( $N=3606)$

\begin{tabular}{|c|c|c|c|c|c|c|c|c|c|c|c|c|c|c|c|}
\hline \multirow[t]{2}{*}{ Variables } & \multirow[t]{2}{*}{$N(\%)$} & \multicolumn{4}{|c|}{ Impact of event } & \multicolumn{4}{|c|}{ Depression } & \multicolumn{4}{|c|}{ Anxiety } & \multicolumn{2}{|l|}{ Stress } \\
\hline & & $\mathrm{R}^{2}$ & $\mathrm{AR}^{2}$ & $\begin{array}{l}\beta \\
(95 \% \mathrm{Cl})\end{array}$ & $\mathbf{P}$ & $\mathrm{R}^{2}$ & $\mathrm{AR}^{2}$ & $\stackrel{\beta}{(95 \% \mathrm{Cl})}$ & $\mathbf{P}$ & $\mathrm{R}^{2}$ & $\mathrm{AR}^{2}$ & $\begin{array}{l}\beta \\
(95 \% \mathrm{Cl})\end{array}$ & $\mathbf{P}$ & $\mathrm{R}^{2}$ & $A$ \\
\hline \multicolumn{16}{|l|}{ Gender } \\
\hline \multirow[t]{2}{*}{ Male } & \multirow{2}{*}{$\begin{array}{l}1014 \\
(28.12 \%)\end{array}$} & \multirow[t]{2}{*}{0.000} & \multirow[t]{2}{*}{0.000} & -0.237 & \multirow[t]{2}{*}{0.197} & \multirow[t]{2}{*}{0.001} & \multirow[t]{2}{*}{0.000} & 0.155 & \multirow[t]{2}{*}{0.150} & \multirow[t]{2}{*}{0.001} & \multirow[t]{2}{*}{0.000} & 0.141 & \multirow[t]{2}{*}{0.108} & \multirow[t]{2}{*}{0.001} & \multirow[t]{2}{*}{0} \\
\hline & & & & $\begin{array}{l}(-0.597 \\
0.123)\end{array}$ & & & & $\begin{array}{l}(-0.056 \\
0.367)\end{array}$ & & & & $\begin{array}{l}(-0.031 \\
0.314)\end{array}$ & & & \\
\hline Female & $\begin{array}{l}2592 \\
(71.88 \%)\end{array}$ & referen & & & & & & & & & & & & & \\
\hline \multicolumn{16}{|l|}{ Age (Years) } \\
\hline \multirow[t]{2}{*}{$\geq 23$} & \multirow{2}{*}{$\begin{array}{l}987 \\
(27.37 \%)\end{array}$} & \multirow[t]{4}{*}{0.001} & 0.000 & & 0.089 & 0.006 & 0.005 & & 0.000 & 0.001 & 0.001 & & 0.134 & 0.008 & 0 \\
\hline & & & & $\begin{array}{l}(-0.053 \\
0.747)\end{array}$ & & & & $\begin{array}{l}(0.307 \\
0.775)\end{array}$ & & & & $\begin{array}{l}(-0.045 \\
0.338)\end{array}$ & & & \\
\hline $21-22$ & 1152 & & & 0.266 & 0.173 & & & 0.201 & 0.079 & & & 0.177 & 0.058 & & \\
\hline & & & & $\begin{array}{l}(-0.117 \\
0.648)\end{array}$ & & & & $\begin{array}{l}(-0.023 \\
0.425)\end{array}$ & & & & $\begin{array}{l}(-0.006 \\
0.360)\end{array}$ & & & \\
\hline$\leq 20$ & $\begin{array}{l}1467 \\
(40.68 \%)\end{array}$ & referen & & & & & & & & & & & & & \\
\hline Residence place & & & & & & & & & & & & & & & \\
\hline Urban & $\begin{array}{l}1537 \\
(4262 \%)\end{array}$ & 0.000 & 0.000 & -0.065 & 0.695 & 0.000 & 0.000 & 0.061 & 0.534 & 0.000 & 0.000 & 0.045 & 0.575 & 0.000 & 0 \\
\hline & & & & $\begin{array}{l}(-0.393 \\
0.262)\end{array}$ & & & & $\begin{array}{l}(-0.131 \\
0.253)\end{array}$ & & & & $\begin{array}{l}(-0.112 \\
0.202)\end{array}$ & & & \\
\hline Rural & $\begin{array}{l}2069 \\
(57.38 \%)\end{array}$ & referen & & & & & & & & & & & & & \\
\hline Education & & & & & & & & & & & & & & & \\
\hline Graduate & $\begin{array}{l}525 \\
(14.56 \%)\end{array}$ & 0.002 & 0.002 & 0.700 & 0.003 & 0.001 & 0.001 & 0.284 & 0.039 & 0.000 & 0.000 & -0.041 & 0.718 & 0.002 & 0 \\
\hline & & & & $\begin{array}{l}(0.241 \\
1.158)\end{array}$ & & & & $\begin{array}{l}(0.015 \\
0.553)\end{array}$ & & & & $\begin{array}{l}(-0.260 \\
0.179)\end{array}$ & & & \\
\hline Undergraduate & $\begin{array}{l}3081 \\
(85.44 \%)\end{array}$ & referen & & & & & & & & & & & & & \\
\hline Major & & & & & & & & & & & & & & & \\
\hline Liberal arts & 663 & 0.002 & 0.002 & 0.500 & 0.007 & 0.001 & 0.001 & -0.240 & 0.028 & 0.000 & 0.000 & -0.082 & 0.359 & 0.001 & 0 \\
\hline & & & & $\begin{array}{l}(0.136 \\
0.865)\end{array}$ & & & & $\begin{array}{l}(-0.454 \\
-0.026)\end{array}$ & & & & $\begin{array}{l}(-0.256 \\
0.093)\end{array}$ & & & \\
\hline Science & $\begin{array}{l}1197 \\
(33.19 \%)\end{array}$ & & & -0.008 & 0.972 & & & -0.079 & 0.551 & & & 0.010 & 0.926 & & \\
\hline & & & & $\begin{array}{l}(-0.451 \\
0.435)\end{array}$ & & & & $\begin{array}{l}(-0.339 \\
0.181)\end{array}$ & & & & $\begin{array}{l}(-0.202 \\
0.222)\end{array}$ & & & \\
\hline Medical & $\begin{array}{l}1746 \\
(48.42 \%)\end{array}$ & referen & & & & & & & & & & & & & \\
\hline Ever had chroni & disease (s) & & & & & & & & & & & & & & \\
\hline Yes & $\begin{array}{l}71 \\
(197 \%)\end{array}$ & 0.002 & 0.001 & 1.433 & 0.016 & 0.014 & 0.014 & 2.459 & 0.000 & 0.007 & 0.007 & 1.407 & 0.000 & 0.011 & 0 \\
\hline & & & & $\begin{array}{l}(0.269 \\
2.598)\end{array}$ & & & & $\begin{array}{l}(1.779 \\
3.138)\end{array}$ & & & & $\begin{array}{l}(0.851 \\
1.964)\end{array}$ & & & \\
\hline No & $\begin{array}{l}3535 \\
(98.03 \%)\end{array}$ & referen & & & & & & & & & & & & & \\
\hline Health conditior & & & & & & & & & & & & & & & \\
\hline Fair or poor & $\begin{array}{l}231 \\
(641 \%)\end{array}$ & 0.004 & 0.004 & 1.323 & 0.000 & 0.040 & 0.040 & 2.373 & 0.000 & 0.040 & 0.040 & 1.935 & 0.000 & 0.036 & 0 \\
\hline & & & & $\begin{array}{l}(0.663, \\
1.983)\end{array}$ & & & & $\begin{array}{l}(1.993 \\
2.753)\end{array}$ & & & & $\begin{array}{l}(1.624, \\
2.245)\end{array}$ & & & \\
\hline Good health & $\begin{array}{l}3375 \\
(93.59 \%)\end{array}$ & referen & & & & & & & & & & & & & \\
\hline
\end{tabular}


Table 2

Association between variables related to the COVID-19 outbreak and the psychological impact during the epidemic $(\mathrm{N}=3606)$

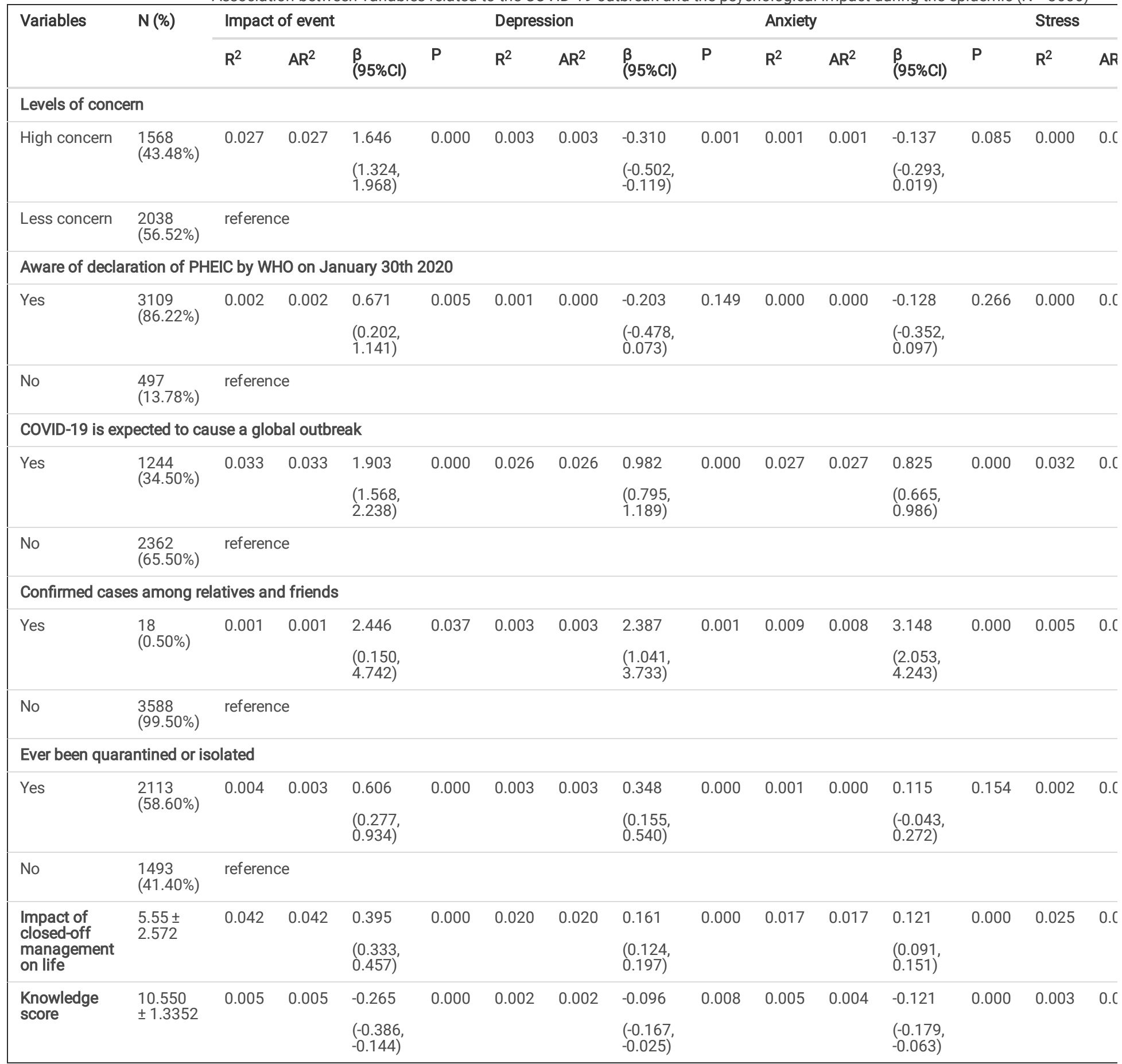

\subsection{Knowledge about COVID-19}

Regarding knowledge of COVID-19, nearly all respondents knew that the first case of COVID-19 was diagnosed in Wuhan, China (99.06\%). $93.37 \%$ could distinguish between influenza virus and the novel coronavirus 2019 (2019-nCoV), 94.43\% understood the difference between SARS and COVID-19, and 90\% agree that the influenza vaccine cannot prevent COVID-19. More than $90 \%$ of the participants knew the suspected source of $2019-n C o V$, the incubation period of the virus infection, and its infectivity during the incubation period. In contrast, only $11.26 \%$ knew that COVID-19 is mainly transmitted by droplets and contact and $11.67 \%$ knew that fever, fatigue, and dry coughing are considered the main clinical manifestations. About half of the people clearly knew the management of Covid-19 as infectious disease (54.05\%) and susceptible population (45.87\%) of COVID-19 in China. As for prevention and treatment, $87.41 \%$ were aware that there is no special treatment for COVID-19, $80 \%$ recognized the efficacy of preventive masks, and $85.97 \%$ mastered the correct way to wear preventive masks during the current epidemic (Table 3). 
Table 3

Knowledge Questionnaire towards COVID-19 $(\mathrm{N}=3606)$

\begin{tabular}{|c|c|}
\hline Questions (correct rate, \% of the total sample) & Options \\
\hline $\begin{array}{l}\text { 1. Where was the first case of the COVID-19 outbreak? } \\
(99.06 \%)\end{array}$ & Beijing; Wuhan; Guangzhou; Hong Kong \\
\hline $\begin{array}{l}\text { 2. Do you agree: the new coronavirus is the influenza } \\
\text { virus. }(93.37 \%)\end{array}$ & Agree; Disagree \\
\hline 3. Do you agree: COVID-19 is SARS. (94.43\%) & Agree; Disagree \\
\hline $\begin{array}{l}\text { 4. Do you agree: influenza or pneumonia vaccine can } \\
\text { prevent COVID-19. (93.76\%) }\end{array}$ & Agree; Disagree \\
\hline $\begin{array}{l}\text { 5. What kind of legal infectious diseases is COVID-19 } \\
\text { listed in China for management? (54.05\%) }\end{array}$ & Category A; Category B, but managed according to category A; Category C; I don't know \\
\hline $\begin{array}{l}\text { 6. What is the possible source of the new coronavirus? } \\
(99.17 \%)\end{array}$ & Wild animals, such as bats; Poultry, such as chickens; Livestock, such as pigs; I don't know \\
\hline $\begin{array}{l}7 * \text { How is the new coronavirus spread? }(23.27 \% \text { and } \\
11.26 \%)\end{array}$ & $\begin{array}{l}\text { Fecal-oral transmission; Respiratory tract droplet transmission; Aerosol transmission; Indirect } \\
\text { contact transmission; Mother-to-child transmission; I don't know }\end{array}$ \\
\hline $\begin{array}{l}\text { 8. What is the susceptible population of COVID-19? } \\
(45.87 \%)\end{array}$ & Middle-aged and elderly; Elderly and children; Generally susceptible; Young and middle-aged \\
\hline $\begin{array}{l}\text { 9. What is the incubation period of new coronavirus } \\
\text { infection? }(90.82 \%)\end{array}$ & Within 24 hours; Within 2 days; $1-14$ days, mostly $3-7$ days; Within 3 weeks \\
\hline $\begin{array}{l}\text { 10. Is there infectivity during the incubation period of } \\
\text { new coronavirus infection? }(99.00 \%)\end{array}$ & Yes; No \\
\hline $\begin{array}{l}11^{*} \text {. Typical symptoms of new coronavirus infection? } \\
(12.34 \% \text { and } 11.67 \%)\end{array}$ & Fever; Fatigue; Dry coughing; Shortness of breath ; Dyspnea \\
\hline $\begin{array}{l}\text { 12. Is there any specific treatment for COVID-19? } \\
(87.41 \%)\end{array}$ & Yes; No \\
\hline $\begin{array}{l}13^{\star} \text {. Which types of masks can prevent COVID-19? } \\
(88.30 \% \text { and } 79.42 \%)\end{array}$ & $\begin{array}{l}\text { Cotton mask; Sponge mask; Medical surgical mask; Activated carbon mask; N95, KN95, DS2, } \\
\text { FFP2 masks }\end{array}$ \\
\hline $\begin{array}{l}\text { 14. What is the correct way to wear the mask during the } \\
\text { current epidemic? }(85.97 \%)\end{array}$ & $\begin{array}{l}\text { Wear masks whenever you go out; Wear masks only in populated areas (i.e. public } \\
\text { transportation); Occasionally wear a mask; Never wear a mask }\end{array}$ \\
\hline
\end{tabular}

\subsection{Factor loadings of perceived threat items and their psychometric properties}

EFA on the 10 items of perceived threat yielded 3 factors (explaining $72.208 \%$ of the total variance; $\mathrm{KMO}=0.871$ ), with satisfactory eigenvalue and factor loadings (eigenvalue $>1$ and factor loading > 0.45) [24]. The three factors identified from the EFA assess respondents' level of perceived risk of being infected and impact to their normal life, with Chronbach's alpha of $0.854,0.881$ and 0.841 (Table 4). 


\begin{tabular}{|c|c|c|c|c|}
\hline Perceived threat (Items) & $\mathbf{N}(\%)$ & $\begin{array}{l}\text { Factor1 } \\
\text { Impact on } \\
\text { life plannin }\end{array}$ & $\begin{array}{l}\text { Factor } 2 \text { Impact of } \\
\text { PHEIC }\end{array}$ & $\begin{array}{l}\text { Factor3 Risk of } \\
\text { infection }\end{array}$ \\
\hline I feel anxious and scared when thinking of COVID-19 & $\begin{array}{l}324 \\
(8.99 \%)\end{array}$ & 0.138 & 0.085 & 0.856 \\
\hline I feel that I can be infected by the virus anytime and anywhere & $\begin{array}{l}278 \\
(7.71 \%)\end{array}$ & 0.091 & 0.057 & 0.891 \\
\hline Worried about being infected and sick & $\begin{array}{l}321 \\
(8.90 \%)\end{array}$ & 0.080 & 0.051 & 0.839 \\
\hline Worried that the epidemic will affect my study plan & $\begin{array}{l}2521 \\
(69.91 \%)\end{array}$ & 0.845 & 0.105 & 0.052 \\
\hline Worried that the epidemic will affect my test plan & $\begin{array}{l}2167 \\
(60.09 \%)\end{array}$ & 0.874 & 0.133 & 0.064 \\
\hline Worried that the epidemic will affect my social plan & $\begin{array}{l}1434 \\
(39.77 \%)\end{array}$ & 0.705 & 0.087 & 0.147 \\
\hline Worried that the epidemic will affect my work plan & $\begin{array}{l}2014 \\
(55.85 \%)\end{array}$ & 0.868 & 0.127 & 0.103 \\
\hline $\begin{array}{l}\text { Worried about the closed-off of tourism and/or trade, affecting international } \\
\text { cooperation and exchanges }\end{array}$ & $\begin{array}{l}1965 \\
(54.49 \%)\end{array}$ & 0.119 & 0.885 & 0.055 \\
\hline $\begin{array}{l}\text { Worried about the lack of goods due to the interruption of import and export } \\
\text { logistics }\end{array}$ & $\begin{array}{l}1819 \\
(50.44 \%)\end{array}$ & 0.121 & 0.915 & 0.076 \\
\hline Worried about rising prices and rising exchange rates & $\begin{array}{l}1927 \\
(53.44 \%)\end{array}$ & 0.149 & 0.861 & 0.070 \\
\hline Eigenvalue & & 3.724 & 1.968 & 1.828 \\
\hline Cumulative $\%$ of variance explained & & $28.123 \%$ & $52.361 \%$ & $75.208 \%$ \\
\hline Cronbach's alpha & & 0.854 & 0.881 & 0.841 \\
\hline
\end{tabular}

\subsection{Prevalence of perceived threat and psychological impacts}

In total, 'Impact on life planning', 'Impact of PHEIC' and 'Risk of infection' were considered threats by study participants. While 2521 participants (69.91\%) reported 'Worried that the epidemic will affect my study plan', only $8.99 \%$ responded that 'I feel anxious and scared when thinking of COVID-19'. The majority of them worried about how the epidemic would affect their tests (60.09\%), work (55.85\%), and social plans (39.77\%). In addition, 278 participants (7.71\%) felt that they can be infected by the virus anytime and anywhere and $8.90 \%$ worried about being infected and sick. Because the WHO declared COVID-19 a PHEIC, $54.49 \%$ were concerned that other countries would close tourism and/or trade with China, which could affect international cooperation and exchanges. More than half of participants (50.44\%) expressed concern about the lack of goods due to the blockage of import-export trade and $53.44 \%$ were worried about rising prices and exchange rates (Table 4).

The IES-6 scale was used to measure the posttraumatic stress of COVID-19 outbreak, which revealed a sample mean score of 7.51 (SD $=4.959)$. An IES-6 cutoff of 10 was used as a measure of PTS [18] and 1234 (34.22\%) were considered to meet the clinical criteria of PTSD (Table 5). The DASS severity ratings of the students are also shown in Table 5 . The proportion of college students reporting mild to extremely severe symptoms of depression, anxiety and stress were $15.70 \%, 13.31 \%$, and $7.10 \%$, respectively. 


\begin{tabular}{|c|c|c|}
\hline Variables & Category & $N(\%)$ \\
\hline \multirow[t]{2}{*}{ Impact of event } & Yes & $1234(34.22 \%)$ \\
\hline & No & $2372(65.78 \%)$ \\
\hline \multirow[t]{5}{*}{ Depression } & Normal (score range: 0-9) & $3040(84.30 \%)$ \\
\hline & Mild (10-13) & $267(7.40 \%)$ \\
\hline & Moderate (14-20) & $215(5.96 \%)$ \\
\hline & Severe $(21-27)$ & $48(1.33 \%)$ \\
\hline & Extremely Severe (28+) & $36(1.00 \%)$ \\
\hline \multirow[t]{5}{*}{ Anxiety } & Normal (score range: $0-7$ ) & $3126(86.69 \%)$ \\
\hline & Mild (8-9) & $135(3.74 \%)$ \\
\hline & Moderate (10-14) & $242(6.71 \%)$ \\
\hline & Severe (15-19) & $45(1.25 \%)$ \\
\hline & Extremely Severe (20+) & $58(1.61 \%)$ \\
\hline \multirow[t]{5}{*}{ Stress } & Normal (score range: $0-14$ ) & $3350(92.90 \%)$ \\
\hline & Mild (15-18) & $116(3.22 \%)$ \\
\hline & Moderate (19-25) & $85(2.36 \%)$ \\
\hline & Severe (26-33) & $46(1.28 \%)$ \\
\hline & Extremely Severe (34+) & $9(0.25 \%)$ \\
\hline
\end{tabular}

\subsection{Associations between background variables and psychological impacts}

Those who were over 20 years old, ever had chronic disease(s), and had fair or poor health condition compared with very healthy were more likely to have PTS, depression, and stress symptoms. Those who believed COVID-19 would cause a global outbreak and had confirmed cases among relatives were significantly associated with having a greater psychological impact of the outbreak. While the degree of impact on daily life by closed-off management was positively correlated with the status of PTS and DASS and knowledge scores were inversely correlated with PTS and DASS status (value of $\beta$ and $P$ see Table 1,2 ).

Male students were more likely to feel more stress $(\beta=0.246, P=0.020)$. Those who were postgraduate and had ever been quarantined or isolated were more likely to have PTS, depression, and stress symptoms. In addition, those who were liberal arts students and had high concerns of the outbreak were more likely to have PTS, but less likely to have depression symptoms. Those who knew that COVID-19 had been announced by WHO as a PHEIC on January 30 were more likely to have PTS symptoms $(\beta=0.671, P=0.005)$. Furthermore, place of residence did not have an association with psychological impacts.

\subsection{Pearson correlation between psychological impacts and perceived threat, perceived social support and coping style}

The IES- 6 and DASS scores were correlated with all proposed psychosocial variables including overall score and subdomain scores of perceived threat, perceived social support, and two forms of coping strategies in anticipated directions. The adverse psychological impacts were positively associated with perceived threat and passive coping strategies (PC), while negatively associated with perceived social support and active coping strategies (AC), except the negative correlation of IES- 6 with active coping $(\beta=0.041, P=0.005)$ (Table 6). 
Table 6

Pearson correlation between perceived threat, perceived social support, coping style and psychological impacts $(N=3606)$

\begin{tabular}{|c|c|c|c|c|c|c|c|c|c|c|c|c|c|c|c|}
\hline \multirow[t]{2}{*}{ Variables } & \multicolumn{4}{|c|}{ Impact of event } & \multicolumn{4}{|c|}{ Depression } & \multicolumn{4}{|c|}{ Anxiety } & \multicolumn{3}{|l|}{ Stress } \\
\hline & $\mathbf{R}^{2}$ & $\mathrm{AR}^{2}$ & $\begin{array}{l}\beta \\
(95 \% \mathrm{Cl})\end{array}$ & $\mathrm{P}$ & $\mathrm{R}^{2}$ & $\mathrm{AR}^{2}$ & $\begin{array}{l}\beta \\
(95 \% \mathrm{Cl})\end{array}$ & $\mathbf{P}$ & $\mathrm{R}^{2}$ & $A R^{2}$ & $\begin{array}{l}\beta \\
(95 \% \mathrm{Cl})\end{array}$ & $\mathbf{P}$ & $\mathrm{R}^{2}$ & $A R^{2}$ & $\begin{array}{l}\beta \\
(95 \% \mathrm{Cl})\end{array}$ \\
\hline \multirow{2}{*}{$\begin{array}{l}\text { Perceived } \\
\text { threat }\end{array}$} & 0.224 & 0.224 & 0.376 & 0.000 & 0.082 & 0.082 & 0.134 & 0.000 & 0.089 & 0.089 & 0.113 & 0.000 & 0.125 & 0.124 & 0.176 \\
\hline & & & $\begin{array}{l}(0.353 \\
0.399)\end{array}$ & & & & $\begin{array}{l}(0.119, \\
0.148)\end{array}$ & & & & $\begin{array}{l}(0.102, \\
0.125)\end{array}$ & & & & $\begin{array}{l}(0.161 \\
0.192)\end{array}$ \\
\hline \multirow{2}{*}{$\begin{array}{l}\text { Risk of } \\
\text { infection }\end{array}$} & 0.228 & 0.228 & 0.930 & 0.000 & 0.092 & 0.091 & 0.346 & 0.000 & 0.133 & 0.133 & 0.340 & 0.000 & 0.144 & 0.144 & 0.465 \\
\hline & & & $\begin{array}{l}(0.874 \\
0.986)\end{array}$ & & & & $\begin{array}{l}(0.310, \\
0.382)\end{array}$ & & & & $\begin{array}{l}(0.312, \\
0.369)\end{array}$ & & & & $\begin{array}{l}(0.428 \\
0.502)\end{array}$ \\
\hline \multirow{2}{*}{$\begin{array}{l}\text { Impact } \\
\text { on life } \\
\text { planning }\end{array}$} & 0.089 & 0.089 & 0.385 & 0.000 & 0.037 & 0.037 & 0.146 & 0.000 & 0.029 & 0.029 & 0.106 & 0.000 & 0.051 & 0.051 & 0.184 \\
\hline & & & $\begin{array}{l}(0.346 \\
0.427)\end{array}$ & & & & $\begin{array}{l}(0.122, \\
0.171)\end{array}$ & & & & $\begin{array}{l}(0.086, \\
0.126)\end{array}$ & & & & $\begin{array}{l}(0.158 \\
0.210)\end{array}$ \\
\hline \multirow{2}{*}{$\begin{array}{l}\text { Impact of } \\
\text { PHEIC }\end{array}$} & 0.060 & 0.060 & 0.502 & 0.000 & 0.014 & 0.013 & 0.140 & 0.000 & 0.013 & 0.013 & 0.112 & 0.000 & 0.023 & 0.023 & 0.195 \\
\hline & & & $\begin{array}{l}(0.437, \\
0.566)\end{array}$ & & & & $\begin{array}{l}(0.101, \\
0.179)\end{array}$ & & & & $\begin{array}{l}(0.080, \\
0.143)\end{array}$ & & & & $\begin{array}{l}(0.154 \\
0.237)\end{array}$ \\
\hline \multirow{2}{*}{$\begin{array}{l}\text { Perceived } \\
\text { social } \\
\text { support }\end{array}$} & 0.001 & 0.001 & -0.017 & 0.023 & 0.072 & 0.072 & -0.071 & 0.000 & 0.042 & 0.041 & -0.044 & 0.000 & 0.050 & 0.050 & -0.064 \\
\hline & & & $\begin{array}{l}(-0.032 \\
-0.002)\end{array}$ & & & & $\begin{array}{l}(-0.080 \\
-0.063)\end{array}$ & & & & $\begin{array}{l}(-0.051 \\
-0.037)\end{array}$ & & & & $\begin{array}{l}(-0.073 \\
-0.055)\end{array}$ \\
\hline \multirow{2}{*}{$\begin{array}{l}\text { Active } \\
\text { coping } \\
\text { (AC) }\end{array}$} & 0.002 & 0.002 & 0.041 & 0.005 & 0.045 & 0.045 & -0.110 & 0.000 & 0.018 & 0.018 & -0.057 & 0.000 & 0.024 & 0.023 & -0.085 \\
\hline & & & $\begin{array}{l}(0.013 \\
0.070)\end{array}$ & & & & $\begin{array}{l}(-0.127 \\
-0.094)\end{array}$ & & & & $\begin{array}{l}(-0.070 \\
-0.043)\end{array}$ & & & & $\begin{array}{l}(-0.103 \\
-0.067)\end{array}$ \\
\hline \multirow{2}{*}{$\begin{array}{l}\text { Passive } \\
\text { coping } \\
\text { (PC) }\end{array}$} & 0.064 & 0.064 & 0.286 & 0.000 & 0.050 & 0.050 & 0.148 & 0.000 & 0.054 & 0.054 & 0.126 & 0.000 & 0.047 & 0.046 & 0.154 \\
\hline & & & $\begin{array}{l}(0.250 \\
0.322)\end{array}$ & & & & $\begin{array}{l}(0.127, \\
0.170)\end{array}$ & & & & $\begin{array}{l}(0.109, \\
0.143)\end{array}$ & & & & $\begin{array}{l}(0.131 \\
0.176)\end{array}$ \\
\hline
\end{tabular}

\subsection{Multivariate correlates of psychological symptoms}

Compare to the group of younger than 20 year old, age greater than 23 years old was positively associated with the depression ( $\beta=0.321, P=0.023)$ and stress subscales $(\beta=0.449, P=0.002)$ of DASS, and age 21 to 22 years was positively correlated to stress $(\beta=0.292 P=0.006)$. Graduate students were more likely to suffer from PTS $(\beta=0.720, P=0.005)$. Liberal arts students were significantly associated with lower DASS depression subscale $(\beta=-0.303, P=0.003)$ as compared to those who were medical students. History of chronic illness was significantly associated with a higher DASS depression subscale $(\beta=1.451$, $P=0.000)$, DASS anxiety subscale $(\beta=0.606, P=0.014)$, and DASS depression subscale $(\beta=1.304, P=0.000)$ scores. Similarly, fair or poor self-rated health condition was significantly associated with a greater psychological impact of the outbreak as compared to those with good health condition (Table 7 ).

Those who were highly concerned about the outbreak $(\beta=1.358, P=0.000)$ and knew the WHO declaration of COVID-19 as a PHEIC on January 30 ( $\beta=0.616$, $P=0.002$ ) were significantly associated with higher IES-6 scores. Those who thought that COVID-19 would cause a global outbreak was significantly associated with a higher IES- $6(\beta=0.567, P=0.000)$ and three DASS subscales scores $(\beta=0.355,0.323$, and 0.415 for depression, anxiety and stress respectively, $P=0.000$ ). Those had confirmed cases among relatives and friends were more likely to have DASS symptoms. The impact of closed-off management on life was significantly associated with a greater psychological impact of the outbreak, while people with a higher outbreak knowledge score were less likely to suffer from adverse psychological symptoms (Table 7).

While the impact of PHEIC was not associated with DASS anxiety subscale, all three dimensions of perceived threat and PC were associated with a higher IES6 and the three DASS subscale scores. In contrast, perceived social support was negatively correlated with depression, anxiety, and stress symptoms. In addition, AC was significantly associated with higher scores in the IES-6 $(\beta=0.038, P=0.010)$, but lower scores in the DASS depressions subscale ( $\beta=-0.069$, $P=0.000)$, DASS anxiety subscale $(\beta=-0.024, P=0.001)$, and DASS stress subscale $(\beta=-0.039, P=0.000)$. In multivariate analysis, variables including gender and history of being quarantined or isolated were not associated with IES-6 and DASS subscale scores (Table 7). 
Table 7

Results of multiple linear regression analysis on IES- 6 and DASS $(N=3606)$

\begin{tabular}{|c|c|c|c|c|c|c|c|c|}
\hline \multirow[t]{2}{*}{ Variables } & \multicolumn{2}{|l|}{ IES } & \multicolumn{2}{|l|}{ Depression } & \multicolumn{2}{|l|}{ Anxiety } & \multicolumn{2}{|l|}{ Stress } \\
\hline & $\beta(95 \% \mathrm{Cl})$ & $\mathbf{P}$ & $\beta(95 \% \mathrm{Cl})$ & $\mathbf{P}$ & $\beta(95 \% \mathrm{Cl})$ & $\mathbf{P}$ & $\beta(95 \% \mathrm{Cl})$ & $\mathbf{P}$ \\
\hline \multicolumn{9}{|l|}{ Gender } \\
\hline \multirow[t]{2}{*}{ Male } & \multirow[t]{3}{*}{-} & & \multirow[t]{3}{*}{ - } & & \multirow[t]{3}{*}{-} & & 0.177 & \multirow[t]{2}{*}{0.084} \\
\hline & & & & & & & $(-0.024,0.377)$ & \\
\hline Female & & & & & & & reference & \\
\hline \multicolumn{9}{|l|}{ Age (Years) } \\
\hline \multirow[t]{2}{*}{$\geq 23$} & -0.438 & \multirow[t]{2}{*}{0.051} & 0.321 & \multirow[t]{2}{*}{0.023} & 0.070 & \multirow[t]{2}{*}{0.430} & 0.449 & \multirow[t]{2}{*}{0.002} \\
\hline & $(-0.877,0.002$ & & $(0.044,0.598)$ & & $(-0.104,0.245)$ & & $(0.165,0.733)$ & \\
\hline \multirow[t]{2}{*}{$21-22$} & -0.055 & \multirow[t]{2}{*}{0.735} & 0.001 & \multirow[t]{2}{*}{0.993} & 0.081 & \multirow[t]{2}{*}{0.327} & 0.292 & \multirow[t]{2}{*}{0.006} \\
\hline & $(-0.373,0.263)$ & & $(-0.199,0.201)$ & & $(-0.081,0.244)$ & & $(0.082,0.502)$ & \\
\hline$\leq 20$ & reference & & & & & & & \\
\hline \multicolumn{9}{|l|}{ Education } \\
\hline \multirow[t]{2}{*}{ Graduate } & 0.720 & 0.005 & -0.091 & 0.572 & - & & 0.077 & 0.649 \\
\hline & $(0.220,1.220)$ & & $(-0.406,0.224)$ & & & & $(-0.256,0.410)$ & \\
\hline Undergraduate & reference & & & & & & reference & \\
\hline Major & & & & & & & & \\
\hline Liberal arts & 0.260 & 0.113 & -0.303 & 0.003 & - & & - & \\
\hline & $(-0.062,0.582)$ & & $(-0.506,-0.100)$ & & & & & \\
\hline Science & 0.035 & 0.857 & -0.207 & 0.086 & & & & \\
\hline & $(-0.341,0.410)$ & & $(-0.444,0.030)$ & & & & & \\
\hline Medical & reference & & & & & & & \\
\hline Ever had chronic dis & & & & & & & & \\
\hline Yes & 0.798 & 0.104 & 1.451 & 0.000 & 0.626 & 0.014 & 1.304 & 0.000 \\
\hline & $(-0.165,1.760)$ & & $(0.844,2.058)$ & & $(0.129,1.123)$ & & $(0.662,1.947)$ & \\
\hline No & reference & & & & & & & \\
\hline Health condition & & & & & & & & \\
\hline Fair or poor health & 0.557 & 0.050 & 1.409 & 0.000 & 1.280 & 0.000 & 1.460 & 0.000 \\
\hline & $(0.001,1.113)$ & & $(1.058,1.760)$ & & $(0.999,1.573)$ & & $(1.089,1.831)$ & \\
\hline Good health & reference & & & & & & & \\
\hline Levels of concern & & & & & & & & \\
\hline High concern & 1.358 & 0.000 & -0.034 & 0.704 & 0.001 & 0.992 & - & \\
\hline & $(1.080,1.636)$ & & $(-0.208,0.140)$ & & $(-0.142,0.143)$ & & & \\
\hline Less concern & reference & & & & & & & \\
\hline Knowing that the $W$ & s a PHEIC on Jar & ary 30 & & & & & & \\
\hline Yes & 0.616 & 0.002 & - & & - & & - & \\
\hline & $(0.224,1.008)$ & & & & & & & \\
\hline No & reference & & & & & & & \\
\hline COVID-19 is expect & reak & & & & & & & \\
\hline Yes & 0.567 & 0.000 & 0.355 & 0.000 & 0.323 & 0.000 & 0.415 & 0.000 \\
\hline & $(0.279,0.855)$ & & $(0.173,0.536)$ & & $(0.175,0.472)$ & & $(0.223,0.607)$ & \\
\hline No & reference & & & & & & & \\
\hline
\end{tabular}




\begin{tabular}{|c|c|c|c|c|c|c|c|c|}
\hline \multirow[t]{2}{*}{ Variables } & \multicolumn{2}{|l|}{ IES } & \multicolumn{2}{|l|}{ Depression } & \multicolumn{2}{|l|}{ Anxiety } & \multicolumn{2}{|l|}{ Stress } \\
\hline & $\beta(95 \% \mathrm{Cl})$ & $\mathbf{P}$ & $\beta(95 \% \mathrm{Cl})$ & $\mathbf{P}$ & $\beta(95 \% \mathrm{Cl})$ & $\mathbf{P}$ & $\beta(95 \% \mathrm{Cl})$ & $\mathbf{P}$ \\
\hline \multirow[t]{2}{*}{ Yes } & 0.996 & 0.297 & 1.520 & 0.012 & 2.513 & 0.000 & 1.961 & 0.002 \\
\hline & $(-0.878,2.870)$ & & $(0.339,2.702)$ & & $(1.546,3.481)$ & & $(0.711,3.212)$ & \\
\hline No & \multicolumn{8}{|l|}{ reference } \\
\hline \multicolumn{9}{|l|}{ Ever been quarantined or isolated } \\
\hline \multirow[t]{2}{*}{ Yes } & 0.105 & 0.444 & 0.159 & 0.067 & - & & 0.070 & 0.447 \\
\hline & $(-0.165,0.375)$ & & $(-0.011,0.330)$ & & & & $(-0.111,0.251)$ & \\
\hline No & \multicolumn{4}{|l|}{ reference } & & & \multicolumn{2}{|l|}{ reference } \\
\hline \multirow[t]{2}{*}{ Impact of closed-off management on life } & 0.152 & 0.000 & 0.067 & 0.000 & 0.047 & 0.001 & 0.077 & 0.000 \\
\hline & $(0.098,0.206)$ & & $(0.033,0.101)$ & & $(0.019,0.075)$ & & $(0.041,0.112)$ & \\
\hline \multirow[t]{2}{*}{ Knowledge score } & -0.255 & 0.000 & -0.083 & 0.013 & -0.093 & 0.001 & -0.109 & 0.002 \\
\hline & $(-0.359,-0.152)$ & & $(-0.148,-0.018)$ & & $(-0.145,-0.041)$ & & $(-0.177,-0.041)$ & \\
\hline \multicolumn{9}{|l|}{ Perceived threat } \\
\hline \multirow[t]{2}{*}{ Risk of infection } & 0.739 & 0.000 & 0.207 & 0.000 & 0.250 & 0.000 & 0.334 & 0.000 \\
\hline & $(0.683,0.794)$ & & $(0.172,0.242)$ & & $(0.222,0.279)$ & & $(0.296,0.371)$ & \\
\hline \multirow[t]{2}{*}{ Impact on life planning } & 0.171 & 0.000 & 0.069 & 0.000 & 0.035 & 0.000 & 0.078 & 0.000 \\
\hline & $(0.133,0.209)$ & & $(0.046,0.093)$ & & $(0.016,0.055)$ & & $(0.052,0.103)$ & \\
\hline \multirow[t]{2}{*}{ Impact of PHEIC } & 0.206 & 0.000 & 0.039 & 0.036 & 0.020 & 0.185 & 0.063 & 0.001 \\
\hline & $(0.148,0.264)$ & & $(0.002,0.075)$ & & $(-0.010,0.050)$ & & $(0.024,0.101)$ & \\
\hline \multirow[t]{2}{*}{ Perceived social support } & -0.011 & 0.128 & -0.039 & 0.000 & -0.023 & 0.000 & -0.034 & 0.000 \\
\hline & $(-0.026,0.003)$ & & $(-0.048,-0.030)$ & & $(-0.030,-0.015)$ & & $(-0.043,-0.024)$ & \\
\hline \multirow[t]{2}{*}{ Active coping (AC) } & 0.038 & 0.010 & -0.069 & 0.000 & -0.024 & 0.001 & -0.039 & 0.000 \\
\hline & $(0.009,0.066)$ & & $(-0.087,-0.051)$ & & $(-0.039,-0.009)$ & & $(-0.058,-0.020)$ & \\
\hline \multirow[t]{2}{*}{ Passive coping (PC) } & 0.164 & 0.000 & 0.122 & 0.000 & 0.091 & 0.000 & 0.102 & 0.000 \\
\hline & $(0.132,0.196)$ & & $(0.102,0.142)$ & & $(0.075,0.108)$ & & $(0.081,0.123)$ & \\
\hline
\end{tabular}

\section{Discussion}

The results of our study revealed a high prevalence of PTS among Chinese college students during the outbreak of COVID-19 virus. More than one-third of participants met the cut-off for PTSD. In comparison, the prevalence of PTS symptoms in the general population during the 2014-2016 Ebola epidemic ranged from $10-27 \%$ [5]. Compared to PTS symptoms, the prevalence of depression, anxiety and stress as measured by the DASS-21 was lower with $15.70 \%$, $13.31 \%$ and $7.10 \%$ of respondents reported mild to extremely severe depressive, anxiety, and stress symptoms. Several factors may have contributed to the difference between the level of PTS and DASS among college students. First, the morbidity rate of Covid-19 infection is relatively low among this age group based on the information publicized on various mass medias [25-27]. Second, the college students were on winter vacation at the early stage of the epidemic during which they may reduce the risk of infection due to their family isolation. Furthermore, compared with other working-age populations college students experience less economic pressure caused by the epidemic.

Compared to similar domestic and overseas studies, the prevalence of PTS and DASS symptoms in this study were lower [28-31]. This might be partly due to the timing of the study, which occurred when the COVID-19 outbreak showed a downward trend of new cases in China and an upward trend overseas. As the epidemic was gradually controlled in China, the psychological reaction among the general population and students was relief. In addition, the different psychological scales used in these studies may lead to different measurement outcomes. Furthermore, the present study explored the psychological response to the COVID-19 epidemic among college students, while the target population of other studies was the general population or medical care workers.

The prevalence of psychological symptoms in this study differ from other similar epidemiological studies in China that found that older students have a lower risk of depression and anxiety [31]. Our findings showed the opposite trend. Compared with Chang's research, the proportion of medical and non-medical students in our study population similar [31]. During our research period, the majority of universities had clearly notified students that the 2020 spring semester was extended, which may increase the pressure of graduation, internships, and employment for older non-medical students. As a result, we found older college students (i.e., over 23 years old) were more likely to report higher levels of depression and stress. Moreover, a previous study revealed gender differences in the psychological impact of the COVID-19 outbreak, which was not found in our study among college students [28]. In addition, older age, heavy 
loads of study, and certain economic pressures make the postgraduate group more prone to PTS symptoms than undergraduate students. Consistent with the results of a domestic study [31], medical students are more prone to depression during public health emergencies such as outbreaks. Two reasons may have contributed to the more severe psychological status seen in medical students. First, out of professional needs, medical students may pay more attention to the epidemic. Second, medical students may be called upon to join local epidemic prevention teams where medical personnel are lacking, which would undoubtedly increase the risk of infection for medical students and their families, thereby increasing their likelihood of suffering from depression.

The study results are in line with the previous study that showed a marked increase in PTS, depression, anxiety, and stress among those who perceived themselves as not very healthy during the COVID-19 outbreak, including those who ever had chronic disease(s) [28]. People with chronic underlying diseases are not only susceptible to infection (especially with the lack of proper protection) but also have a poor prognosis once diagnosed. During the closed-off period, unhealthy participants might have the need to seek medical treatment for their chronic disease(s) or other health issues, however, these individuals may choose to stay at home until their life is endangered by their disease. With the absence of medical care during the epidemic, these unhealthy populations were at an increased risk of depression, anxiety and stress.

With easy access to the internet, the majority of respondents can get instant updates on news related to the COVID-19 outbreak, which was not as possible during SARS in 2003. In this study, we found that access to instant information has positive and negative consequences. On the one hand, the information related to COVID-19 outbreak can help keep students informed on the epidemic development, including source of infection, route of transmission and preventive measures, etc. The more knowledge students have, the more confidently they can respond to the outbreak. On the other hand, in today's world of instant information, students may suffer from PTSD due to high concern about the outbreak. After WHO declared COVID-19 a PHEIC on January 30 , more than half of students worried about poor economics and trade as well as the lack of goods and rising prices due to the declaration. In addition, about a third of the respondents believed that COVID-19 would cause a global outbreak. Under the circumstances at that time, students with such concerns were prone to adverse psychological effects, including PTSD, anxiety, depression and stress.

Moreover, when the epidemic is closely related to one's own life, it undoubtedly causes people to panic. Our results revealed that those who had confirmed cases among relatives and friends reported perceived risk of infection and those that believed that lives were affected by the outbreak and closed-off management response experienced PTS and higher levels of depression, anxiety, and stress. In addition, most of the participants worried that the epidemic would affect their studies, tests, work, and social activities. Staying motivated at home can be tough for students, since home is often regarded as a place kept away from study and work. Therefore, college students are undoubtedly a distinct psychologically vulnerable population during the home isolation period, due to their unique developmental stage in life and the need to meet academic expectations.

In addition, the results in this study indicate the important influence of perceived social support and coping styles on psychological health. Close and confiding social networks can reinforce individual abilities to manage stressful situations and increase individual resilience levels [32, 33]. Persons who lack social support are prone to various mental health issues. On the contrary, strong social support seems to be a protective factor for psychological impact, which was further verified in this study. Coping strategy is an individual's cognitive evaluation toward stress and the measures adopted to balance one's mental state. A positive coping style can optimize an individual's subjective cognition, improve the ability of handling problems individually, and improve emotion. Those who adopted active coping styles may explain why they were less likely to suffer from adverse psychological outcomes than those who responded negatively during the COVID-19 outbreak.

Due to the overwhelming international situation regarding COVID-19, it is important to provide target guidance for preventing and relieving adverse psychological impacts among college students. First, target vulnerable populations, including those who are unhealthy, major in medicine, graduate students, hold an pessimistic attitude towards the COVID-19 epidemic, lack social support, and adopt passive coping styles since these populations are at risk for mental disorders. In addition, students should be reminded to identify the reliability of information and to get relevant knowledge/news from authoritative agencies. Schools and teachers should recommend official website to students to reduce panic caused by false news. At the same time, up-to-date and evidence- based information should be promoted to ease the nervousness of students during the home isolation period. Furthermore, fully equipped online facilities to minimize the impact of closed-off management on students' routine learning and work tasks. Finally, create a socially supported environment, whether it is an online or in-person surrounding community. Smartphone applications are widely accepted among college students and schools, health authorities, and public welfare psychological counseling organizations could consider providing online or hotline psychological interventions to prevent or reduce possible psychological problems among students. At the same time, reminding students to maintain a daily routine at home, dressing up like they were attending school, attending on-line classes on time, and regularly arranging self-study to create the illusion of studying on campus during the home isolation period [34].

In summary, the findings from this study provide a basis for implementing measures to improve the mental health among college students during the outbreak of COVID-19 and have a reference value for identifying students who may have a high risk of adverse psychological problems. Our study has a number of strengths, including a large sample size and robust statistical analysis. However, there are limitations that need to be considered when interpreting our findings. First, the generalizability of our findings is impacted given the results were possibly due in part to nonrandom selection of the sample. In addition, the uncontrolled observational study of college students and the cross-sectional nature of the data warrant further longitudinal studies to determine the predictors of adverse psychological effects during the outbreak. Finally, due to anonymous network response and self-reported levels of psychological impact, anxiety, depression and stress, our results may not be comparable to clinical psychological diagnosis.

\section{Conclusions}

During the initial phases of the COVID-19 pandemic, this observational cross-sectional clinical study revealed that more than one-third of participants suffered from adverse psychological impact, including PTS, depression, anxiety, and stress symptoms. Students who were older, unhealthy, majoring in medicine,

Page $12 / 15$ 
graduate students, highly concerned about the outbreak, had confirmed cases among relatives and friends, held an pessimistic attitude towards the epidemic, perceived threat, lacked knowledge and social support, and adopted passive coping styles were associated with a greater psychological impact of the COVID19 outbreak. Our findings can aid in formulating psychological interventions to improve mental health of college students during epidemics of infectious disease.

\section{Abbreviations}

\section{COVID-19}

Coronavirus Disease 2019

IES-6

Impact of Event Scale-6

\section{DASS}

Depression, Anxiety and Stress Scale

PSSS

The perceived social support scale

SCSQ

Simplified Coping Style Questionnaire

EFA

Exploratory factor analysis

PTS

Posttraumatic stress

PTSD

Posttraumatic stress disorder

\section{WHO}

World Health Organization

PHEIC

Public Health Emergency of International Concern

SARS

Severe acute respiratory syndrome

MERS

Middle East respiratory syndrome

AC

Active coping

PC

Passive coping

IES-R

Impact of Event Scale-revised

SD

Standard deviation

\section{Declarations}

Ethics approval and consent to participate This study has been approved by the Ethics Committee of Jining Medical University of Shandong Province on February 12th, 2020 (approval number: JNMC-2020-KY-001).

Consent for publication Not applicable.

Availability of data and materials The original data generated from this study and the analyzed results will be available from the corresponding author upon reasonable request.

Competing interests None.

Funding Asian Regional Special Cooperation Fund of National Health Commission of the People's Republic of China (BLXM01) and Innovation Fund for Medical Sciences sponsored by Chinese Academy of Medical Sciences (2017-I2M-B\&R-17, 2019-I2M-2-005)

Authors' contributions Xiao-You Su, Ming-Yu Si prepared the first draft. You-Lin Qiao provided overall guidance. You-Lin Qiao, Xiao-You Su, Wen-Jun Wang and Ming-Yu Si managed the overall project. Xiao-You Su, Wen-Jun Wang, Xiao-Fen Gu, Li Ma, Jing Li, Shao-Kai Zhang and Ze-Fang Ren were responsible for the questionnaire survey of people in seven geographical regions of China. Xiao-You Su and Ming-Yu Si analyzed data. Yu Jiang and Yuan-Li Liu finalized the manuscript on the basis of comments from other authors.

Acknowledgements Not applicable.

\section{References}


1. WHO. Weekly Epidemiological updates of Coronavirus disease 2019 (COVID-19), 14 September 2020. https://www.who.int/docs/defaultsource/coronaviruse/situation-reports/20200914-weekly-epi-update-5.pdf?sfvrsn=cf929d04_2 (accessed September 17, 2020)..

2. National Health Commission of the People's Republic of China. Sept 17: Daily briefing on novel coronavirus cases in China, 17 September. 2020. http://en.nhc.gov.cn/2020-09/17/c_81680.htm (accessed September 17, 2020).

3. World Health Organization (WHO).WHO characterizes COVID-19 as a pandemic, [EB/OL]. Geneva, Switzerland: World Health Organization; 2020. https://www.who.int/emergencies/diseases/novel-coronavirus-2019/events-as-they-happen (accessed June 28, 2020).

4. Main A. Zhou Q, Ma Y. Luecken LJ, Liu X. Relations of SARS-related stressors and coping to Chinese college students' psychological adjustment during the 2003 Beijing SARS epidemic. J Couns Psychol. 2011 Jul,58(3):410 - 23. doi: 10.1037/a0023632.

5. Jalloh MF, Li WS, Bunnell RE, Ethier KA, O'Leary A, Hageman KM, et al. Impact of Ebola experiences and risk perceptions on mental health in Sierra Leone, July 2015. Bmj Global Health 2018, 3(2).

6. Zhang R, Jiang T, Li N, Wang Z, Liu B, Fang L, et al. [The negative psychology for the public in Zhejiang province during the epidemic of human H7N9 avian influenza]. Zhonghua Yu Fang Yi Xue Za Zhi. 2015 Dec;49(12):1073-9. Chinese. PMID: 26887302.

7. Ng Kee Kwong KC, Mehta PR, Shukla G, Mehta AR. COVID-19, SARS and MERS: A neurological perspective. J Clin Neurosci. 2020 Jul;77:13-6. doi:10.1016/j.jocn.2020.04.124.

8. Sun Y, Tao F, Hao J, Wan Y. The mediating effects of stress and coping on depression among adolescents in China. J Child Adolesc Psychiatr Nurs. 2010 Aug;23(3):173-80. doi:10.1111/j.1744-6171.2010.00238.x.

9. Wong JG, Cheung EP, Cheung V, Cheung C, Chan MT, Chua SE, et al Psychological responses to the SARS outbreak in healthcare students in Hong Kong. Medical teacher, 2004, 26(7), 657-659. doi:10.1080/01421590400006572.

10. Zimet GD. Dahlem NW, Zimet SG. Farley GK. The multidimensional scale of perceived social support. J Pers Assess 52 1998, 52:30-41.

11. Chou KL. Assessing Chinese adolescents' social support. the multidimensional scale of perceived social support. Personality Individ Differ. 2000;28:299307.

12. Folkman S. Lazarus R. Coping as a mediator of emotion. J Pers Soc Psychol 1998, 54:466-75.

13. Xie Y. Reliability and validity of the simplified coping style questionnaire. Chin J Clin Psychol. 1998;6:114-5. 16:114-115.

14. Kraaij V, Garnefski N, Maes S. The joint effects of stress, coping, and coping resources on depressive symptoms in the elderly. Anxiety Stress Coping. 2002;15(2):163-77.

15. Zhan S, Wu T, Ren T, Qin Y, Hu Y, Wong TW, et al. [The cross-sectional study of awareness and practice of SARS epidemic in community residents in Beijing]. Beijing Da Xue Xue Bao Yi Xue Ban. 2003 May 31;35 Suppl:95 - 8. Chinese. PMID: 12914230.

16. Liu ZR, Huang YQ, Dang WM, Liu M, Li SR. [Study on the psychosocial status and related factors in three universities during severe acute respiratory syndrome epidemic in Beijing]. Zhonghua Liu Xing Bing Xue Za Zhi. 2004 Jul;25(7):594-7. Chinese. PMID: 15308040.

17. Smith RD. Responding to global infectious disease outbreaks. lessons from SARS on the role of risk perception, communication and management. Soc Sci Med. 2006 Dec;63(12):3113-23. doi:10.1016/j.socscimed.2006.08.004.

18. Thoresen S, Tambs K, Hussain A, Heir T, Johansen VA, Bisson JI. Brief measure of posttraumatic stress reactions: Impact of Event Scale-6. Social Psychiatry and Psychiatric Epidemiology 2010, 45(3):405-412.

19. Zhang MWB. Ho CSH, Fang P. Lu YX, Ho RCM. Usage of Social Media and Smartphone Application in Assessment of Physical and Psychological WellBeing of Individuals in Times of a Major Air Pollution Crisis. Jmir Mhealth and Uhealth 2014, 2(7).

20. Lovibond P, Lovibond S. The structure of negative emotional states:comparison of the Depression Anxiety Stress Scales (DASS) with the Beck Depression and Anxiety Inventories[J]. Behaviour Research and Therapy 1995, 33(03).

21. Taouk M, Lovibond P, Laube R. Psychometric properties of a Chinese version of the 21-item Depression Anxiety Stress Scales(DASS21). In: Sydney:Cumberland Hospital. 2001.

22. Chan RCK, Xu T, Huang J, Wang Y, Zhao Q, Shum DHK, et al. Extending the utility of the Depression Anxiety Stress scale by examining its psychometric properties in Chinese settings. Psychiatry Res. 2012;200(2-3):879-83.

23. Wang K, Shi H, Geng F, Zou L, Tan S, Wang Y, et al. Cross-cultural validation of the Depression Anxiety Stress Scale-21 in China. Psychological assessment 2015.

24. Comrey A, Lee, HB: A First Course in Factor Analysis, 2nded. Hillsdale, NJ: Lawrence Erbaum Associates 1992.

25. Guan WJ, Ni ZY, Hu Y, Liang WH, Ou CQ, He JX, et al. Clinical Characteristics of Coronavirus Disease 2019 in China. N Engl J Med. 2020;382(18):1708-20. doi:10.1056/NEJMoa2002032.

26. Garg S, Kim L, Whitaker M, et al. Hospitalization Rates and Characteristics of Patients Hospitalized with Laboratory-Confirmed Coronavirus Disease 2019 COVID-NET, 14 States, March 1-30, 2020. MMWR Morb Mortal Wkly Rep. 2020;69(15):458-64. doi:10.15585/mmwr.mm6915e3. Published 2020 Apr 17.

27. $10.1136 /$ bmj.m1985

Garg S, Kim L, Whitaker M, O'Halloran A, Cummings C, Holstein R, et al. Features of 20133 UK patients in hospital with covid-19 using the ISARIC WHO Clinical Characterisation Protocol: prospective observational cohort study. BMJ. 2020;369:m1985. Published 2020 May 22. doi:10.1136/bmj.m1985.

28. Wang C, Pan R, Wan X, Tan Y, Xu L, Ho CS, et al. Immediate psychological responses and associated factors during the initial stage of the 2019 coronavirus disease (COVID-19) epidemic among the general population in China. Int J Environ Res Public Health. 2020;17(5):E1729.

29. Li Z, Ge J, Yang M, Feng J, Qiao M, Jiang R, et al. Vicarious traumatization in the general public, members, and non-members of medical teams aiding in COVID-19 control. Brain Behav. Immun. 2020;10(20). 
30. $1591(20) 30586-9$

Moccia L, Janiri D, Pepe M, Dattoli L, Molinaro M, De Martin V, et al. Affective temperament, attachment style, and the psychological impact of the CoVID19 outbreak: an early report on the Italian general population. Brain Behav Immun. 2020 Apr 20:S0889-1591(20)30586-9. doi: 10.1016/j.bbi.2020.04.048.

31. Chang J, Yuan Y, Wang D. [Mental health status and its influencing factors among college students during the epidemic of COVID-19]. Nan Fang Yi Ke Da Xue Xue Bao. 2020 Feb 29;40(2):171-176. Chinese. doi: 10.12122/j.issn.1673-4254.2020.02.06.

32. Xu Q, Li S, Yang L. Perceived social support and mental health for college students in mainland China: the mediating effects of self-concept. Psychol Health Med. 2019 Jun;24(5):595-604. doi:10.1080/13548506.2018.1549744.

33. Brailovskaia J, Schönfeld P, Zhang XC, Bieda A, Kochetkov Y, Margraf J A Cross-Cultural Study in Germany, Russia, and China: Are Resilient and Social Supported Students Protected Against Depression, Anxiety, and Stress? Psychol Rep. 2018 Apr;121(2):265-281. doi: 10.1177/0033294117727745.

34. Papalampropoulou-Tsiridou M. Finding motivation while working from home as a PhD student during the coronavirus pandemic. Nature. 2020 Apr 28. doi:10.1038/d41586-020-01292-x. 